\title{
Peter Salner nielen o etnicite, judaizme a vedeckom bádaní...
}

\author{
Peter Salner not only about ethnicity, Judaism \\ and scientific research...
}

DOI: 10.31577/EtnoRozpra.2021.28.2.08

\section{Marta Botiková}

\section{Acknowledgement}

Vydanie príspevku bolo podporené grantom VEGA č. 1/0194/20 Morálne naratívy o náboženských a etnických skupinách vo vyučovaní vybraných predmetov na základných školách.

\section{Kontakt / Contact}

Prof. PhDr. Marta Botiková, CSc., Filozofická fakulta Univerzity Komenského v Bratislave, Gondova 2, 81102 Bratislava, Slovenská republika, e-mail: marta.botikova@uniba.sk

ORCID (iD https://orcid.org/0000-0002-7160-4958

\section{Ako citovat' / How to cite}

Botiková, M. (2021). Peter Salner nielen o etnicite, judaizme a vedeckom bádaní... Etnologické rozpravy, 28(2), 79-87. https://doi.org/10.31577/EtnoRozpra.2021.28.2.08

PhDr. Peter Salner, DrSc. je dlhoročný pracovník Ústavu etnológie a sociálnej antropológie SAV. Do ústavu (v tom čase Národopisný ústav SAV) nastúpil v roku 1975 ako interný vedecký ašpirant. Svojou kandidátskou dizertačnou prácou sa stal priekopníkom urbánno-etnologického výskumu na Slovensku. Postupne rozšíril svoje vedecké záujmy aj na sociálnu kultúru židovskej minority na Slovensku. Dnes patrí k našim najvýznamnejším odborníkom v týchto témach.

Ak hovoríme o problematike, ktorej sa už nejakú dobu venujem, t. j. téme Rómov, vztah Spočiatku sa orientoval na oblast' sociálnej kultúry v prostredí mesta. Osobitnú pozornost' venoval kultúre každodennosti, v historických aj súčasných súvislostiach. Na báze tohto výskumu sa zrodila pod jeho vedením úspešná kolektívna publikácia Taká bola Bratislava (1991), ocenená aj Cenou Egona Ervína Kischa, pozitívne prijatá aj širokou kultúrnou obcou. P. Salner sa tiež intenzívne zaoberal otázkami sociálnych vzt’ahov v mestskom spoločenstve. Problematika diverzifikácie, tolerancie a intolerancie, otázky etnických 
menšín sa objavujú vo viacerých čiastkových prácach a editorských počinoch. Východiskovými boli jeho štúdie k otázkam židovskej identity. Zároveň sa podiel'al na rozsiahlom výskume, z ktorého vznikol nielen ojedinelý fond výpovedí pamätníkov holokaustu, ale aj vedecky a l'udsky pôsobivá monografia Prežili holokaust (1997). V rokoch 2011 až 2020 P. Salner pokračoval v skúmaní židovskej identity a jej premien od 19. do 21. storočia, s dôrazom na obdobie po skončení druhej svetovej vojny a holokaustu, resp. po roku 1989. Skúmal aj medzigeneračnú komunikáciu v rodine, pripomínanie holokaustu v židovskej komunite, rovnako aj politiky spomínania na celoštátnej úrovni.

Peter Salner je aktívny aj v populárno-vedeckej tvorbe, aktívne spolupracuje s občianskymi združeniami a mimovládnymi organizáciami. Bol jedným z iniciátorov vzniku Dokumentačného strediska holokaustu v Bratislave. Ako občiansky aktivista, ale aj ako reprezentant židovskej komunity sa angažoval pri rozvíjaní židovsko-krest’anského dialógu.

Vd’aka odbornosti, ale najmä zásluhou rozsiahlej a kvalitnej vedeckej práce a publikačnej činnosti si Peter Salner získal uznanie slovenskej a zahraničnej vedeckej komunity, ako aj širokej verejnosti. K životnému jubileu bol ocenený Medailou SAV za podporu vedy - jedným z najvyšších vyznamenaní SAV. Oprávnene ho možno zaradit k najvýraznejším osobnostiam súčasnej slovenskej etnológie.

Milý Peter, úvodné fakty k nášmu rozhovoru sme čerpali z dostupných stránok, na ktorých Ťa predstavujú z rôznych aspektov Tvojich činností a s rôznymi ciel'mi predstavovania. My dvaja si možno viac, či tesnejšiu spoluprácu pamätáme z prvých desatročí Tvojho nástupu do sféry vedeckého bádania a písania. Neviem, či niekedy zaznela otázka, čo to bol za nápad, kde v Tebe skrsla myšlienka, íst’ študovat’ etnológiu, ktorá sa v tom čase pod názvom etnografia a folkloristika vyučovala na rovnomennej katedre Filozofickej fakulty Univerzity Komenského v Bratislave?

Najskôr d’akujem za pozvanie na tento rozhovor a otázky, ktoré si položila. Študovat' (podla vtedajšej terminológie) národopis mi predtým nikdy nenapadlo, ale ako realita ma to dost' agresívne napadlo zvonka. Vlastne som ani nevedel, že tento odbor existuje. Rozhodoval som sa v roku 1969 a pôvodne som chcel íst’ na archeológiu. Nebola síce v zozname otváraných predmetov, ale moja mama tvrdila, že je federácia, tak bude aj archeológia. A komu verit', ked' nie vlastnej matke? Tak som sa prihlásil a dostal odpoved', že sa predsa len neotvára. Zahrával som sa s myšlienkou, že pôjdem do Brna alebo budem rok pauzovat', ale opät’ zasiahla vyššia moc v podobe mamy. Pracovala v Univerzitke, bola „pri prameni“ a prišla s tým, že národopis je niečo podobné a keby ma to nebavilo, môžem o rok prestúpit'. Opät’ som poslúchol a nel'utujem. Na pohovoroch boli moje oblúbené predmety dejepis a slovenčina, z maturity som bol nadupaný, takže to nebol problém. Horšia bola zákerná otázka, prečo som si vybral práve národopis. Mal som síce prečítanú Melicherčíkovu Teóriu národopisu (1945), ale to mi nepripadalo ako presvedčivý argument. Nakoniec som niečo vykoktal a komisii to zjavne stačilo. Po prvom ročníku som o prestupe na archeológiu neuvažoval ani náhodou.

Jedna moja dávna spomienka sa spája so slávnostou promócie z malého doktorátu, tam sme stáli zoradení podl’a abecedy, Salner, Sigmundová... V tom čase si sa naplno začal venovat’ etnológii mesta, mestskej štvrte, ulíc v Tvojom okolí. Bolo to objavné, aj odvážne. My všetci sme sa „trepali“ čím najd’alej z domu, do hôr a dolín, aby sme využili priaznivý vplyv kultúrneho šoku, a Ty si si tento šok odpustil. Prostredie, ktoré si skúmal, 
bolo Tvojím prostredím. Nehrozilo tu akési uspokojenie, otupenie pozornosti, že by si všetko, čo sa okolo Teba dialo, považoval za „samozrejmé“?

$\checkmark$ porovnaní s klasickou predstavou národopisca som bol v mnohých ohladoch „netradičný“ - mestský človek, ktorý sa vždy hrdo deklaroval ako „priatel' asfaltu a betónu“, nepočujúci, navyše žid s nie najlepším kádrovým posudkom. Dokonca aj humor som mal iný, Milan Leščák raz povedal, že „taký zvláštny“. Spomenuté handicapy ma nútili hladat' si vlastnú, zaujímavú a pokial' možno ideologicky prijatel'nú parketu. Pôvodne som uvažoval o etnopsychológii, nakoniec sa, najmä pod vplyvom prednášok Petra Skalníka, vyvrbila urbánna etnológia. Ked’ sme si mali vybrat' tému diplomoviek, navrhol som súčasnú mestskú svadbu a profesor Podolák bez váhania súhlasil. Prácu som úspešne obhájil a moja budúca dráha bola vytýčená, aj ked'sa to spočiatku nezdalo. Pol roka som pracoval $v$ Mestskom dome kultúry a osvety (oficiálne v pozícii skladníka), potom ma na prekvapenie mnohých mojich známych prijali na ašpirantúru $\vee$ Národopisnom ústave SAV. Výskum súčasnej mestskej rodiny som robil hlavne v bratislavskom Starom meste, kde som odjakživa žil. (Inak Milan Leščák raz povedal, že svojimi prácami si pišem životopis. Mal, aj nemal pravdu. Bol to môj život, ale nie životopis...) Malo to plusy i mínusy, ale pozitíva prevažovali. Zaujímala ma štruktúra a formy rodiny, zbieral som najmä kvantitatívne údaje, ktoré som vylepšoval rozhovormi a rôznymi formami pozorovania. Paradoxne mi pomáhali spomenuté handicapy. Vd’aka nim som sa necítil ako „súčast vzorky“, čo mi pomáhalo udržiavat kritický odstup. Prvé zistenia prijala odborná obec s určitým dešpektom. Zistenie, že v skúmanom prostredí žije vel’a rozšírených rodín, zmietol jeden z pedagógov slovami, že to nemožno tak povedat', lebo oni spolu bývat' nechcú. Iný mi neskôr poradil, že vo vlastnom záujme nemám v budúcnosti kritizovat bytovú politiku socialistickej spoločnosti. Pri obhajobe povestný profesor Robek držal prednášku na tému „a ted’ vám ukážu, proč je Salner nebezpečím pro naši vědu“. Naštastie mal na mysli „neetnologické“ využívanie kvantitatívnych postupov a nie nejaké ideologické chyby, ale nebolo mi vtedy všetko jedno... O pár rokov neskôr som objavil „prekrásny nový svet“ spoločenského života Bratislavy v medzivojnovom období. Tam už prípadné uspokojenie či otupenie pozornosti nehrozilo. A kolektívna monografia Taká bola Bratislava potvrdila, že zvolená téma a obdobie oslovujú aj verejnost'.

Aby si si náhodou vel'mi „nehovel“, vybral si sa aj Ty na výskum obcí pred zánikom, obce Riečnica a Harvelka na Kysuciach, tam kde sa začínalo stavat' budúce vodné dielo. Nehovorím, bola tam dobrá výskumnícka spoločnost', „bratislavská kaviareň“ sa na pozvanie Petra Marákyho presunula na kysucké dvory. Kolegovci Gabika Kiliánová, Arne Mann, právnik Peter Mozolík, tiež som sa dostala do tejto výskumníckej skupiny..., čo Ťa zaujalo, inšpirovalo počas výskumu okrajového regiónu, kolonizačného, rozbrázdeného pracovnými migráciami, minulými, a vtedy aj súčasnými, s perspektívou budúcich - s perspektívou vystahovania l'udí preč z rodnej obce, z poznaného do neznámeho...

Tvoje otázky smerujú do „temnej minulosti“ a pri úvahách o odpovediach som klesol ešte hlbšie, až k prvému študentskému výskumu ludového liečenia v Podhájskej. Urobil som si podrobný dotazník, formát A5, previazaný modrou stužkou, poctivo som sa snažil dostat’ od každého odpovede na všetky otázky, preto je logické, že (paradoxne naštastie pre mňa), to dopadlo blbo. Vd’aka tomu som totiž okrem iného pochopil, že 1. informátor je partner, ktorého treba chápat', no netvárit sa, že som ako on/ona, pretože nie som; 2. dotazník je pomôcka, ale nie biblia; 3. nie sú dôležité moje vedomosti, ale informáto- 
ri; a napokon poznanie, že fakty fungujú v súvislostiach, ktoré nie sú vždy viditel’né, ale existujú, preto ich treba hladat'.

Skúmal som rodinu len v Riečnici a dodnes na to rád spomínam. Vidiecke prostredie mi zrazu nerobilo problém, bavili ma l'udia, terén aj príroda. Navyše neskôr spolupráca s genetikom Vladimírom Ferákom ukázala, že kvantitatívne údaje (v tomto prípade z matrík) môže etnológia využit aj vo vidieckom prostredí a najmä to, že máme čo ponúknut prírodným vedám... Z týchto poznatkov a skúseností som žil ešte dlhé roky.

Nevyhol a myslím, že si sa ani nevyhýbal aj inému vidieckemu terénu - družstevná dedina Sebechleby. Žírna, pohodová, voňajúca chlebom a vínom... Akú perspektívu si získal v tejto výskumnej úlohe?

Sebechleby mi opät potvrdili možnosti, ktoré ponúka spracovanie kvantitatívnych údajov pre pochopenie niektorých aspektov mestskej aj vidieckej rodiny. Využíval som domové knihy, v ktorých boli zachytení všetci obyvatelia jednotlivých domov. Tieto zistenia som doplnil klasickým výskumom a myslím, že to nebolo márne. Napriek tomu ma prostredie družstevnej dediny vel'mi neoslovilo. S potešením som preto privítal, že sa táto kapitola môjho vedeckého života skončila relatívne rýchlo a bezproblémovo. Nebola to moja šálka kávy.

Myslím, že chronologicky do tohto obdobia spadá aj Tvoja intenzívna práca na pôde Národopisnej spoločnosti Slovenska, ked' si pracoval v orgánoch spoločnosti, aj ako redaktor Národopisných informácií, predchodcu Etnologických rozpráv. Čo pre Teba predstavovala táto práca, čo Ťa k nej motivovalo a aké Ti priniesla poznatky a úžitky?

Vo vtedajšej Slovenskej národopisnej spoločnosti (meno sa neskôr zmenilo, pretože skratku SNS dostala do povedomia verejnosti Slovenská národná strana), som na prelome 80. a 90. rokov dve či tri funkčné obdobia pôsobil ako tajomník. Z rôznych dôvodov to boli zaujímavé časy. Zmenil sa stav spoločnosti, neskôr aj režim a to sa premietlo do aktivít SNS. Bavila ma spolupráca s vtedajšou predsedníčkou Emkou Drábikovou a verím, že ani ona nemala so mnou problém. Podobne ako ja, milovala plávanie a ked' sme po Valnom zhromaždení v Nitre spoločne odchádzali z funkcií, stretli sme sa v hotelovom bazéne a vždy, ked' sme sa vo vode míňali, blažene sme sa na seba usmievali.

Dobré bolo, že Spoločnost’ finančne a organizačne podporovala študentské aj kolektívne výskumy, podiel'ala sa na príprave rôznych konferencií a raz za tri roky usporiadala hojne navštevované valné zhromaždenie, na ktoré prichádzali aj kolegovia z Čiech, Pol'ska či Mad’arska. Osobitne dôležité bolo pre mňa valné zhromaždenie v Poprade. Preto, že na ešte nedávno exotickú tému urbánnej etnológie sa prihlásilo prekvapujúco vel'a referátov, ale aj z iného dôvodu. Kolega Arne Mann zorganizoval na počest’ Andreja Kmet’a výstup na Kriváň (určite sa na to pamätáš, ved' ste tam spolu s Jankom vyliezli tiež).

Áno, ten národopisný výstup na Kriváň (17. 9. 1981, pozri aj Mann, 1982: 115-116) bolo výborné podujatie. Arne Mann mal pre nás pripravené citáty z Andreja Kmeta, Ty v poltopánkach. Mykola Mušinka v obleku, nič nikomu nevadilo, išli sme. Teraz, ked' o tom hovoríš, potvrdzujem, veru si nás prekvapil, stal sa z Teba turista, a nie hocijaký, rovno vysokohorský!

82 Pre mňa to bola prvá vysokohorská túra, dovtedy som na niečo podobné ani nepomyslel. 
Niekol'ko rokov som tuho fajčil a vtedy som sa vyhýbal každému kroku navyše. Mal som len obyčajné poltopánky a pred začiatkom som sa s Arnem seriózne radil, či hemendex predstavuje pre túto príležitost' vhodné raňajky. Napokon som to zvládol (určite vd’aka tomu, že som krátko predtým s fajčením prestal) a odvtedy som, na prekvapenie všetkých známych, pravidelne a nadšene zdolával tatranské vrcholy dovtedy, kým ma nezradili kolená. Pomohlo mi to fyzicky, ale ešte viac psychicky. Pochopil som, že čo nemám v nohách, musím mat’ v hlave a že tá moja zvládne viac, než som si dovtedy myslel. K Tvojej poznámke doplním, že po chvíli to vzdal Mišo Hvišč. Mal síce správne topánky, ale ho tlačili, takže som s hrôzou videl, ako si stahuje ponožky a kontroluje krvavé pl'uzgiere.

Spomienku na peripetie s Národopisnými informáciami som nedávno pripravil pre tento časopis, ale myslím, že zatial' nevyšla. Milan Leščák mi po príchode do ústavu zveril post výkonného redaktora. Mal som dve zdanlivo jednoduché povinnosti: zabezpečit príspevky a ich rozmnoženie. Na to sa používali špeciálne blany. V rokoch normalizácie režim evidoval a starostlivo kontroloval ich použitie. Zásadne nám dávali menej, než bol plánovaný počet strán, preto sme sa usilovali doplnit ich kde sa dalo, ako sa dalo, bez ohl'adu na ich kvalitu. Boli sme štastní, že číslo vôbec vyšlo, čast' čitatel'ov však bežne a oprávnene kritizovala zlú čitatel'nost' textov...

Návrat do Bratislavy a vel'koplošná akcia výskumu rodiny a obyčajov prostredníctvom štandardizovaných dotazníkov... Ako dnes hodnotíš tento výskumný projekt?

Bol to hlavne výskum rodinných obyčajov a robili sme ho spolu s Vierou Feglovou. Získali sme zaujímavý materiál, a najmä nové skúsenosti o stave problematiky aj spoločnosti. Dotazník bol síce anonymný, ale aj tak odpovede často prezrádzali obavy vyplňovatelov z prípadných sankcií režimu... Nespomínam na to rád a s dnešným poznaním by som tento výskum bud' vôbec nerobil, alebo zvolil celkom iný prístup.

Ústavné semináre - aby som zostala v chronologickej osi, vtedy nazývané „Semináre mladých“, dnes by to asi bolo work in progress. Prekvapil si, že v niektorých témach si šiel do sporu s autoritou bádatel'ky rodinného života, Soňou Švecovou. Pripomeniem Ti témy: život mládeže, tiež koncept rozptýlená (mestská) rodina. Nebolo to každodenné. Ako sa na tieto - podotýkam - výlučne akademické, nie osobné, spory, pozeráš $z$ dnešného pohl'adu?

Tieto semináre boli dôležité z hladiska prezentovaných tém, ale ešte viac ako príprava na "dospelý" vedecký život. Nútili nás nielen pripravit úvodný vstup, ale hlavne učili diskutovat', pripravit' si otázky, formulovat' improvizované odpovede. Možno sa to nezdá, ale vtedy som bol vel'ký trémista, vystúpenia som si vopred napísal, doma nacvičil a poctivo prečítal slovo za slovom. Ked' som mal na tomto fóre prezentovat' dizertáciu, asi som sa zbláznil a z ničoho nič vyhlásil, že pripravený text (bol v taške), som zabudol doma. Naštastie som to zvládol a odvtedy až na výnimočné prípady hovorím radšej z hlavy. Väčšinou je to zaujímavejšie pre poslucháčov a mne občas $v$ hlave vyskočia súvislosti, ktoré mi predtým nenapadli. A samozrejme nechýba ani strach z blamáže v prípade „okna“.

Tu musím vstúpit' do deja... Veru, bolo pre mňa nepochopitel'né, že si si text "zabudol doma". Reku, ved' ten Peter býva na pár minút od ústavu, čo si nezbehne pre text? Ved' by sme naňho počkali...Teraz po mnohých rokoch s prekvapením, a musím povedat', $s$ rešpektom počúvam, ako to bolo naozaj. 
Pokial' ide o druhú čast' otázky, na spory so Soňou Švecovou si nepamätám, hoci je to možné. $Z$ domácich diskusií s otcom a bratom som bol zvyknutý pozerat' na problém z rôznych strán, hl'adat', či neexistuje iné možné alebo dokonca lepšie riešenie, a to som neskôr aplikoval aj v odbore. Fenomén rozptýlenej rodiny som objavil v štúdii nemeckej sociologičky Elisabeth Pfeil, ktorá sa s ním stretla počas svojich výskumov v Hamburgu. Pokúsil som sa aplikovat' jej názory na bratislavské prostredie. Fungovalo to a pomohlo mi pochopit, že naše mestské rodiny nežijú tak izolovane a odcudzene, ako sa dovtedy myslelo.

Pamätám sa, že si bol aj vnímavým čitatel’om mnohých druhov literatúry. Prekvapivé a novátorské boli tak aj Tvoje recenzie na literárne diela, ktoré boli obrazom rôznych aspektov kultúry a spôsobu života. Niet pochýb o tom, že rád čítaš. Čo práve čítaš?

To súvisí so spomínaným hladaním súvislostí. Moja súkromná definícia etnológie znie, že je to jediná veda, ktorá sa zaoberá normálnym životom normálnych l'udí. Majú široké spektrum názorov a záujmov, ktoré si musíme všímat aj my. Možno prvým takýmto pokusom bola pre mňa recenzia knihy Farleyho Mowata Nehaňte vlka (1981; pozri Salner, 1982: 534). Pokúsil som sa konfrontovat' jeho formy výskumu s našou praxou a text som poslal do Slovenského národopisu. Potom som sa zlakol a požiadal pani riaditel'ku Filovú, aby mi ho vrátila. Väčšinou mi vychádzala v ústrety, v tomto prípade ale moju žiadost striktne odmietla, pretože je to vraj zaujímavé. Takto povzbudený som potom s chutou písal aj o prácach sociológov, psychológov, matematikov či fyzikov...

Mrzí ma, že dnes zanedbávame malé formy, ako sú recenzie, eseje či rozhovory. (Preto som vel'mi rád, že sa podarilo vydat’ Dvojrozhovor o pamäti, etnológii a meste (2020), v ktorom si s Monikou Vrzgulovou vzájomne kladieme otázky aj odpovedáme). Na jednej strane je to racionálne, pretože pracoviskám ani autorom v platnom hodnotiacom systéme neprinášajú body. Zároveň sa sami okrádame o priestor pre fantáziu, improvizáciu, vnútorný dialóg. Práve vd’aka takýmto textom som pochopil, že inšpirácia i informácie sú ukryté nielen $v$ odbornej literatúre, ale kto hladá, nájde $v$ každom žánri. Rád čítam detektívky. Čistia hlavu a navyše techniky pátrania i mnohé fakty často ponúkajú inšpiráciu a paralely s terénnym výskumom. Kedysi sme fantazírovali s Vierou Nosál'ovou, že o tom napíšeme, ale skutek utek.

Pani docentka Horváthová tiež rada čítala detektívky, striehla na ne v antikvariáte na Sedlárskej, zvykla sa tam cestou z katedry skoro denne zastavit'.

Viem, vyznala sa nielen v zvykosloví, mala obrovskú škálu vedomostí. Často a radi sme sa na túto tému bavili. Nemali sme rovnakých favoritov, ale práve preto to bolo zaujímavé, zábavné a poučné.

Až teraz sme s Monikou Vrzgulovou pripravili esej Vedecký výskum ako detektívne pátranie. Vyjde ešte tento rok. Zaujíma ma aj literatúra faktu a odborné či beletristické knihy so židovskou tematikou. Momentálne mám rozčítaný historicko-psychologický Prípad Spinoza od Irvina D. Yaloma, detektívku Michaela Connellyho a Skok do prázdného bazénu, čo je knižný rozhovor so známym izraelským spisovatel’om Amosom Ozom.

Taká bola Bratislava - skvelý projekt, ktorý na stránkach Vašej publikácie (spolu s V. Feglovou, D. Lutherom, ale aj archivárkami, historičkami V. Obuchovou a E. Mannovou) 
urobil z Bratislavy plnohodnotné mesto s kaviarňami a viechami, so životom, plynúcim v starých štvrtiach... Je to ocenená (Cena E. E. Kischa 1992) a stále oceňovaná publikácia. Výskumy tejto témy si publikoval aj v popularizačných monografiách Premeny Bratislavy 1939-1993 (1998), Bratislavské kaviarne a viechy (2006). Čo znamenal pre Teba návrat do mesta? Myslím, výskumný návrat?

Túto záležitost’ som už spomenul v rôznych súvislostiach. Bol to ale návrat do iného mesta a inej doby, než $v$ akej sme $v$ osemdesiatych rokoch žili. Oslobodil ma od šedej každodennosti normalizačného obdobia a zároveň zdôraznil dvojtvárnost̉ spoločnosti. Fakty som čerpal z rozhovorov s pamätníkmi, dobovej tlače, ale najmä z memoárovej literatúry. Fascinovali ma komunistickí literáti, ktorí pravidelne opisovali hrôzy medzivojnového kapitalistického Československa a jedným dychom s nostalgiou spomínali, že $v$ kaviarňach či viechach verejne a nahlas $v$ sporoch $s$ ideovými protivníkmi (teda prívržencami vtedajšieho režimu) kritizovali existujúce pomery. Pre mňa a mojich súčasníkov to bolo nepredstavitel'né.

Z uvedených dôvodov som (a určite nielen ja) písal tieto texty s chutou a radostou.

Ďakujem za prihrávku o popularizácii. Mojím ciel'om je nielen „povedat’, čo treba“, ale aj zaujat’ a zabavit', bez ohl'adu na to, či ide o monografiu, novinový článok alebo štúdiu do vedeckého časopisu. Nie každému to vyhovuje, preto som rád, že tento trend podporuje nielen hororista Stephen King (O písaní, kolegom vrelo odporúčam), ale aj známy a seriózny slovenský historik Ivan Kamenec (knižný Rozhovor s dejinami).

Po roku 1989 si sa zapojil do svetového projektu výskumu spomienok tých, ktorí prežili holokaust. Môžeš nám podrobnejšie opísat', ako sa začala a potom rozvijala Tvoja účast' na projekte, či si projekt našiel Teba?

Našiel si ma, a prišiel v pravý čas. Mesto ma už nenapĺňalo, chcel som sa zaoberat' židovskou problematikou a hl'adal som konkrétne témy. Ked' ma oslovil Martin Bútora, neváhal som ani chvil'ku a dostal som sa k svojmu životnému projektu. Začiatky boli tažké, riešili sa technické problémy (kamery a kameramani, miesta nahrávania). Pomohol vtedajší riaditel' ústavu Dušan Ratica. Dal nám k dispozícii ústavné štúdio na Jakubovom námestí, sprostredkoval kontakt na výborných kameramanov z Divadelného ústavu. Projekt na Slovensku menežovala Nadácia Milana Šimečku. Americký iniciátor (The Fortunoff Video Archive for Holocaust Testimonies, ktorý je súčastou Yale University) bol spokojný a po odovzdaní pôvodne plánovaných 50 kaziet financoval pokračovanie až na konečných 148 svedectiev. V textovom prepise je to viac než 5000 strán, v ktorých sa skrýva množstvo faktov, inšpirácie, ale hlavne bolesti a utrpenia. Ešte teraz, takmer štvrt' storočia po ukončení, $v$ ňom nachádzam množstvo nových informácií a súvislostí. Vel'mi náročná, niekedy až bolestivá práca, ale (aspoň zatial') môj najdôležitejší projekt. Získal som vel'a nových poznatkov o holokauste, židovskej komunite, ale aj o mojej rodine a sebe.

Ďalšiu dôležitú, pre mňa vel'mi emotívnu a z odborného hladiska intenzívnu tému priniesla rekonštrukcia Pamätníka Chatama Sofera. V pravidelných kontaktoch s ortodoxnými veriacimi som sa dozvedel vela o ich názoroch, spôsobe života, psychológii a hodnotách. Podiel'al som sa na riešení zložitých a dovtedy pre mňa neznámych problémov, ktoré boli spojené s príkazmi a zákazmi prác na židovských cintorínoch. Mnohé z toho som zužitkoval o desaţročie neskôr v knihe o židovskom pohrebe. Mojou hlavnou úlohou 
bolo sprostredkovat' kontakty dvoch nie celkom kompatibilných svetov, aby sa predišlo nechceným urážkam. Nebolo jednoduché vysvetlit emancipovaným a úspešným slovenským ženám, že ortodoxní veriaci sa nesmú dotknút cudzích žien a preto im nepodávajú ruku, alebo presviedčat' bratislavských odborníkov, že praxou overené postupy musia nahradit' z ich pohl'adu zbytočne zložitými a nepraktickými riešeniami, lebo investor na tom trvá. Myslel som, že po stáročiach života v diaspóre majú židovskí odborníci skúsenosti s riešením všetkých potenciálnych problémov a hlboko som sa mýlii. S pobaveným prekvapením som sledoval, že niektoré religiózne zádrhele vyriešili bratislavskí inžinieri a robotníci, a nie rabínske autority, ktoré dozorovali priebeh stavby.

Tiež to bola príležitost' výrazne zmenit’ metodológiu zberu údajov. Predtým si robieval najmä štandardné etnografické rozhovory a pozorovania, tiež si objavil pre našu vedu viaceré archívne zdroje. $V$ tomto projekte to bol predsa len iný žáner - rozprávania zo života. Ako hodnotís teraz, spätne tento tvoj obrat v metóde?

V každom projekte je nevyhnutné hladat' optimálny prístup. Musí vyhovovat výskumníkovi a zároveň zodpovedat zadaniu a ani tento nebol výnimkou. Bál som sa najmä, čo na to povie môj sluch. Neraz bolo skutočne náročné počúvat' pozorne aj 2-3 hodiny bez prestávky, ale vd’aka pochopeniu svedkov aj mojich kolegýň (pri každom nahrávaní boli dvaja moderátori) sa mi to podarilo zvládnut'. Ale inak som s touto metódou nemal nijaký problém a s radostou ju používam aj d’alej, momentálne napríklad v rámci projektu Súčasné obrazy socializmu.

Určite si zostal verný aj svojmu komplexnému pozorovaniu a materiál si zbieral v d’alších výskumoch židovskej rodiny a spoločenstva, vo výskume k otázkam viery a náboženského života, vo výskume venovanom všedným dňom, sviatkom, v minulosti aj súčasnosti, $v$ tragédiách aj s humorom... Otvoril si mnohé d’alšie témy, napísal si sériu kníh k problematike procesov tradície i asimilácie, histórie, ako aj etnografickým pohl’adom na židovstvo. Cítiš ešte nejakú podlžnost' k téme, komunite a k sebe ako k autorovi? Inými slovami, aké sú Tvoje najbližšie pracovné plány?

Ako nás poučil Jan Werich, nikdy nic nikdo nemá míti za definitivní. Zatial' som nevyčerpal ani seba, ani témy, ktorým sa venujem. Teší ma, že som zvládol aj také, ktoré ma predtým nebavili (sviatky) či dokonca odpudzovali. Preto si vel'mi vážim monografiu o židovskom pohrebe, ale aj niektoré d’alšie, možno pre iného okrajové publikácie.

Chcel by som scelit moje vedomosti a priniest čím komplexnejší obraz sociálnej kultúry židov na Slovensku od konca 19. storočia dodnes. Predpokladá to spojit čiastkové poznatky starších kníh a štúdií, znovu prebehnút archívny a etnologický materiál, prevetrat skúsenosti z dvoch desatročí pôsobenia na Židovskej náboženskej obci, pridat' nové poznatky a súvislosti, vyhladat' fotografie, ktoré niekedy povedia viac, než slová. Ked' k tomu príde, nevyhnem sa opät' „antisalámovej metóde“ - ked' krájaš, zmenšuje sa, pridaním nových informácií korpus naopak rastie... Sprievodným javom bude nevyhnutne opakovanie (nielen preto, že je matkou múdrosti). Občas na margo toho počúvam, že treba publikovat' len „hotové“ príspevky. Vtedy si spomeniem na staršieho kolegu Milana Chlebanu. $V$ autobuse mi raz objasnil svoju vedeckú stratégiu. Ako múzejný pracovník bude najskôr najmenej 20 rokov pracovat $v$ teréne a potom začne písat' knihy. Neviem, čo vyskúmal, pretože predčasne zomrel skôr, než stihol napísat' prvú. S ním odišlo aj všetko, čo mal v hlave. Nechcel som dopadnút ako on... 
Mám ešte jeden, možno kacírsky, zámer. Disponujem materiálom, ktorý sa dotýka širokého spektra tém. Pri jeho analýze som dospel k záveru, že poznanie a pochopenie prebieha zdola nahor a nie naopak. Proces sa začína v teréne, literatúre, materiáli. „Hlava“ vo forme teórií prichádza na scénu až neskôr... Naopak to podla mňa nefunguje.

Pri opätovnom čítaní mojich odpovedí som si uvedomil, že „antisalámová metóda“ sa prejavuje aj tým, že vety často nekončím bodkou, výkričníkom či otáznikom. Prednost’ dávam trojbodke, pretože signalizuje mne i čitatel'ovi, že problém nie je celkom uzavretý a možno teda skôr či neskôr očakávat' pokračovanie, doplnenie či upresnenie...

Na záver sa chcem pod’akovat' za Tvoje otázky. Opät potvrdili starú židovskú (a etnologickú) múdrost', že sú dôležitejšie než odpovede. Pretože bez otázok niet odpovedí...

Prajem Ti úspešné napíňanie Tvojich plánov a vízií a d’akujem za rozhovor!

\section{Referencie}

Kamenec, I. (2019). Rozhovor s dejinami: Ivan Kamenec o cestách slovenskej histórie s Miroslavom Michelom. Bratislava: Hadart.

King, S. (2018). O písaní: všetko čo viem o svojom remesle. Bratislava: Ikar.

Mann, A. B. (1982). Výstup etnografov na Kriváň na počest' Andreja Kmeta. Slovenský národopis, 30(1), 115-116.

Melicherčík, A. (1945). Teória národopisu. Liptovský sv. Mikuláš: Tranocius.

Mowat, F. (1981). Nehaňte vlka. Bratislava: Obzor.

Salner, P. (1982). FARLEY MOWAT: Nehaňte vlka. Slovenský národopis, 30(3), 534.

Salner, P. (1997). Prežili holokaust. Veda: Bratislava.

Salner, P. (1998). Premeny Bratislavy 1939-1993 (Etnologický pohlad na dynamiku sociálnych procesov). Veda: Bratislava.

Salner, P. (2006). Bratislavské kaviarne a viechy. Bratislava: Marenčin PT.

Salner, P. (2014). Požehnaný spravodlivý sudca (Súčasné formy židovského pohrebu). Bratislava: Ústav etnológie SAV.

Salner, P. (Ed.). (1991). Taká bola Bratislava. Bratislava: Veda.

Vrzgulová, M. (2020). Dvojrozhovor. O pamäti, etnológii a meste. Bratislava: Marenčin PT. 